\title{
Philanthropy movement's response to government policy in negotiating COVID-19 in Indonesia
}

\author{
Nanda Harda Pratama Meiji*, Abdul Kodir, Sumarmi, Ardyanto Tanjung \& Annisa Fathin \\ Dianah \\ Universitas Negeri Malang, Kota Malang, Indonesia \\ Muhammad Asyrofi Al Kindy \\ Nalanda University, Rajgir, India
}

\begin{abstract}
The COVID-19 pandemic has spread throughout the world, including Indonesia. This problem becomes important and raises concerns for the Indonesian people. The government has an essential role in protecting the community. Besides, policies are also needed for prevention and negotiating of COVID-19 so that the impact that is felt does not spread. This study aims to explain the response of the philanthropic movement to government policies in dealing with COVID-19 in Indonesia. This study used qualitative research methods. The data collection process was carried out through interviews with the COVID-19 response team, NGOs, and local communities. The results of this study indicate that the policies set by the government have not been maximized in dealing with the impact of COVID-19, especially the problems associated with basic needs and health facilities for the community. The Negotiation of COVID-19 in Indonesia, which seemed terrible, finally prompted various philanthropic movements to help others and improve the capabilities of people who affected by COVID-19.
\end{abstract}

Keywords: Policy, Negotiating COVID-19, Philanthropy Movement, Response, Government

\section{INTRODUCTION}

The pandemic coronavirus disease (COVID-19) is a problem that is being faced in more than 200 countries in the world. Indonesia was also severely affected by COVID-19, where the death rate reached $8.9 \%$ at the end of March 2020 (WHO 2020). Concern for public health and social action must be taken by individuals, institutions, communities, local and national governments and international agencies to slow or stop the spread of COVID-19. Unfortunately, the pandemic has been spread into the micro-condition of society.

Indonesia and the United States initially underestimated severe COVID-19 dangers. Meanwhile, other countries, such as Vietnam and Singapore, chose to act quickly by warning the public about the risks of the virus. They even imposed strict rules to protect their people. Vietnam, which since early January has set a lockdown and provided incentives for the low and lower-middle class. Likewise, the Chinese state imposed a lockdown during the Chinese New Year celebrations. These countries are not waiting for the COVID-19 pandemic to turn into a disaster and have taken strategic steps to overcome the outbreak (Hidayat et al. 2020).

Meanwhile, the Indonesian government does not even want to set a regional quarantine, one of which is because the government objected to covering the living costs of residents and livestock during the quarantine period. This makes many low-economic or informal workers still have to struggle to make a living amid the pandemic (Nasruddin \& Haq 2020). The government has

*Corresponding author: nanda.harda.fis@um.ac.id 
prioritized handling the economic impacts that may occur due to the epidemic. This can be seen from the government's action of disbursing 103 billion Rp to promote the tourism sector for fear of reducing foreign tourists due to this pandemic.

But social strength is present in Indonesia precisely because of the weak role of the state (Djalante et al. 2020). A survey from Alvara Research of 1,223 respondents showed that $50.4 \%$ of them said the government was slow to respond to COVID-19. Even $60 \%$ of survey respondents also felt that the information provided by the government was unclear. Another survey from the Saiful Mujani Research Center found that the central government is perceived to be slower to move than local governments. This shows that the government's movement has not been optimal, either from education or direct action to respond to COVID-19 (Mujani \& Irvani 2020). The negotiating of COVID-19 in Indonesia, which seems terrible, has finally led to the emergence of various philanthropic movements. On social media, the community enlivened the action by using \#rakyatbanturakyat, a form of community solidarity in helping others amid the COVID-19 pandemic. This shows that there is still a strong social awareness and sensitivity in the community in anticipating the COVID-19 pandemic.

\section{METHODS}

This study used qualitative research methods. This research focuses on several areas connected to community solidarity to erase the pandemic. The data collection process was carried out through several stages, namely, direct interviews and telephone calls, considering that currently access to several areas was limited, observation, and literature study. The interview process was carried out in-depth and openly using a purposive sampling technique. Some of the informants that will be interviewed include the COVID-19 Response Team, NGOs, and local communities.

Meanwhile, a focused discussion group process was carried out with several local communities and local communities who took the initiative to make efforts to reduce the impact of COVID-19. The data analysis in this study used thematic analysis. This analysis was carried out through several stages (Bryman 2012). First, examining the results of the interview transcripts. After that, coding the results of the interview transcripts from several discourses and classifying the results of the interviews based on the topics discussed. And the last one is to interpret findings from predetermined ideas.

There are several questions that will be answered in this research, including First, has the government in general been successful in dealing with the impact of the COVID-19 pandemic? Second, how do people assess government policies on quarantine and PSBB? Third, are government actions that prioritize economic stability understandable? Last, what role should the government play in dealing with the impact of COVID-19?

\section{RESULT AND DISCUSSION}

Based on the data, the number of COVID-19 cases continues to increase, and the government has an essential role in handling COVID-19. The number of COVID-19 cases in Indonesia has not yet decreased, which is the concern of various parties. Various regulations issued by the government, one of which is: Government Regulation Number 21 of 2020 concerning Large-Scale Social Restrictions (PSBB) in the Framework of Accelerating COVID-19 Negotiating and issued by the Ministry of Health through Minister of Health Regulation number 9 of 2020 concerning Guidelines for Large-Scale Social Restrictions In the Context of Accelerating COVID-19 Negotiation. With the issuance of this policy, it is hoped that it can reduce the increase in the number of COVID-19 cases. Still, in fact, until now (22 June 2020), the number of COVID-19 cases in Indonesia has continued to increase (Djalante et al. 2020; Nasruddin \& Haq 2020).

In handling the COVID-19 problem, the Indonesian government prefers a two-way policy path, namely its substantive policy (prevention) while focusing on economic improvement policies. Two 
approaches that are implemented simultaneously cause their implementation to be less than optimal and inconsistent, and even there tends to be a miscoordination between the central government and regional governments (Astuti \& Mahardhika 2020). In the end, the two goals to be achieved, namely breaking the chain of the spread of the virus and improving the economy could not be reached; in fact, it tends to get worse.

Such government actions sacrifice people instead of saving the investment climate. The government should stop the spread of COVID-19 by guaranteeing health services for the people and providing adequate facilities for health workers while ensuring the people's basic needs. The economy is not only about winning, selling and accumulating profits, but also about mutual cooperation to humanize people. We should give them hope for a better life in the future.

The crisis due to COVID-19 is currently coinciding, so that the impact is intensely felt by vulnerable groups who are getting worse, including business groups that need crowds, groups of casual daily workers, street vendors, workers affected by layoffs, farmers, the poor, and so on. In this situation, it is understandable that the government does not dare to take lockdown steps in this phenomenon, because the risk leads to an economic disaster, which automatically has implications for other social impacts (Abodunrin et al. 2020). It may not be worse than the economic crisis in 1998, but the government at least need to give safety and prosperity in basic needs.

This is an unfortunate thing because in the midst of the dilemma faced by the community to remain silent and limit their social movements, the government does not provide basic needs to the community, especially marginalized people who really need help (Indradi et al. 2020). In the long term, this crisis underscores the need for individual states to expand Medicaid and for federal and state governments to take coordinated action to strengthen their insurance markets, expanding healthcare facilities and provider capacities focused on underserved and developing populations and geographic areas (Millett et al. 2020).

Everyone has the potential to be affected by COVID-19, both upper class and lower-middle-class economic people. Meanwhile, there are many deaths due to hunger every year, not even inferior to COVID-19. But the case is not that busy, because it does not attack the middle class and above. In this context, the pandemic strikes anyone regardless of their social and economic level. The case is that the effects are different. For the upper-middle class, they can hoard a lot of food when they have to carry out self-isolation or quarantine. Meanwhile, the middle and lower level, which is vulnerable groups have no choice to get some food without quarantine. If they want to stay at home, there are two threats that will be faced. Firstly, the danger of death from hunger, and second, the threat of dying from a pandemic.

Unfortunately, PSBB does not provide the social security needs of the people. People are restricted from leaving their homes without a guaranteed life. Even though Indonesia has a quarantine qaw where the government has an obligation to secure the lives of its citizens and livestock. This means that if you use a quarantine policy, citizens will receive economic guarantees. PSBB is, on the contrary, the government recommends physical distancing and social distancing, but residents must think for themselves how to find food.

PSBB is precisely the reason for companies or factories to unilaterally terminate their employment, even if they do not get severance pay. From this situation, the government is proven to have failed to guarantee the lives of its people. Work from Home (WFH) is impossible for those who work in the informal sector. PSBB limits residents who daily survive looking for daily income, such as pedicab drivers who are empty of passengers, street vendors in various places who can no longer work, and most of the people affected by COVID-19 who have jobs that require direct interaction. For example, pedicab drivers, masseuse workers, hawkers and scavengers who do not get income because of how many areas have been locked down.

Another thing is the intergenerational context that sometimes plays a role in the social realm. In fact, if you look deeper, both the younger and older generations have an equally important role in dealing with the pandemic. However, the narrative that develops on social media actually seems to describe a younger generation who is more indifferent to the epidemic and has made the spread of COVID-19 even more out of control. Whereas on the other hand, if we look at social communities 
in reducing the risk of a pandemic, it appears from the creative ideas of young people who are then supported by the older generation in the context of policy or financial aspects. On the one hand, this also shows that youth have a role in every era where there is chaos or happiness in society (Meiji 2016; Anderson 2019). The emergence of social communities in the midst of a pandemic shows that social capital, both young and old, is still vital in the context of solving problems at the grassroots.

This problem is the main reason for some community solidarity movements in various big cities in Indonesia to help others in the form of donations, building people's kitchens and food solidarity. Citizen volunteerism should not be considered a panacea to meet public needs (Bovaird et al. 2016) or an opportunity for the state to cancel responsibility (McLennan et al. 2016).

\section{CONCLUSION}

Every day the COVID-19 numbers of cases and victims who die due to the pandemic in Indonesia continue to grow. The social and economic impacts are felt by the people of Indonesia. However, the Indonesian government was slow to respond to the COVID-19 pandemic until it was finally declared a national disaster. The government, which prioritizes economic recovery rather than fulfilling the welfare of the community, has resulted in implementing inoptimal policy implementation. Such government action is at the expense of the people. The government should stop the spread of COVID-19 by guaranteeing public health services, providing adequate health worker facilities while ensuring the people's needs. This phenomenon has triggered the emergence of philanthropic movements in various big cities in Indonesia to show solidarity and initiatives to help others, especially those affected by COVID- 19 .

\section{REFERENCES}

Abodunrin, O., Oloye, G. and Adesola, B. (2020) 'Coronavirus Pandemic and Its Implication on Global Economy', International Journal of Arts, Languages and Business Studies (IJALBS).

Anderson, B. (2019) REVOLOESI PEMOEDA: Pendudukan Jepang dan Perlawanan di Jawa 1944 - 1946. Jakarta: Marjin Kiri.

Astuti, P. B. and Mahardhika, A. S. (2020) 'COVID-19: How does it impact to the Indonesian economy?', Jurnal Inovasi Ekonomi. doi: 10.22219/jiko.v5i3.11751.

Bovaird, T. et al. (2016) 'Activating collective co-production of public services: influencing citizens to participate in complex governance mechanisms in the UK', International Review of Administrative Sciences. doi: $10.1177 / 0020852314566009$.

Bryman, A. (2012) 'Social research methods Bryman', OXFORD University Press.

Djalante, R. et al. (2020) 'Review and analysis of current responses to COVID-19 in Indonesia: Period of January to March 2020', Progress in Disaster Science. doi: 10.1016/j.pdisas.2020.100091.

Hidayat, R. et al. (2020) 'Test, Trace, and Treatment Strategy to Control COVID-19 Infection Among Hospital Staff in a COVID-19 Referral Hospital in Indonesia', Acta medica Indonesiana.

Indradi, A. R. I. S. A. H. et al. (2020) 'Politik Hukum Pemerintah dalam Penanganan Pandemi COVID-19', Universitas Gajah Mada.

McLennan, B., Whittaker, J. and Handmer, J. (2016) 'The changing landscape of disaster volunteering: opportunities, responses and gaps in Australia', Natural Hazards. doi: 10.1007/s11069-016-2532-5.

Meiji, N. H. P. (2016) 'Pendidikan Politik dalam Kuasa Simbolik: Kajian mengenai Dinamika Politik Anak Muda yang Tergabung dalam Partai Politik di Kota Malang', Jurnal Sosiologi Pendidikan Humanis. doi: 10.17977/um021v1i22016p103.

Millett, G. A. et al. (2020) 'Assessing differential impacts of COVID-19 on black communities', Annals of Epidemiology. doi: 10.1016/j.annepidem.2020.05.003.

Mujani, S. and Irvani, D. (2020) 'Sikap dan Perilaku Warga terhadap Kebijakan Penanganan Wabah COVID-19', Politika: Jurnal Ilmu Politik. doi: 10.14710/politika.11.2.2020.219-238.

Nasruddin, R. and Haq, I. (2020) 'Pembatasan Sosial Berskala Besar (PSBB) dan Masyarakat Berpenghasilan Rendah', SALAM: Jurnal Sosial dan Budaya Syar-i. doi: 10.15408/sjsbs.v7i7.15569.

WHO (2020) 'Coronavirus disease (COVID-2019) situation reports', World Health Organisation. 